\title{
COMMENTS
}

\section{OBSCENITY AND THE POST OFFICE: REMOVAL FROM THE MAII UNDER SECTION 1461}

It is my deep conoiction . . that one of the most serious moral and social problems in the United States today is the multi-million dollar mail-order traffic in obscenity. The records show quite clearly that the Post Office Department, over the years, has diligently tried to keep the mails clear of indecent malter, even though it has been subjected frequently to attack and ridiculed by those who hope to profit personally from untestricted mailings, or by those who, confusing liberty with license, unzittingly give them assistance. ${ }^{1}$

\section{ARTHUR E. SUMTMERFIELD \\ Postmaster General of the United States}

But it does not follow that an administrative official may be delegated the power first to determine what is good for the public to read and then to force compliance with his ideas by putting editors who do not follow them at a competitive disadvantage ....We believe that the Post Office officials should experience a feeling of relief if they are limited to the more prosaic function of seeing to it that "neither snow nor rain nor heat nor gloom of night stays these couriers from the swift completion of their appointed rounds."'2

\section{ARNOLD, J., in Esquire v. Walker}

At issue is the role of the Post Office in the protection of public morality. The Postmaster General and Judge Arnold expressed the opposing viewpoints. Each viewpoint has numerous adherents; ${ }^{3}$ each is subject to criticism. On the one hand, it seems anomalous for the Post Office to attempt to regulate public morality; on the other, it seems anomalous to compel the government to foster obscenity by enabling its broadcast distribution. Although the Post Office has

1 Statement of the Postmaster General, Hon. Arthur E. Summerfield, Obscene Matter Sent Through the Mail, Hearings Before the Subcommittee on Postal Operations of the House Committee on Post Office and Civil Service, 86th Cong., 1st Sess., 4 (1959) (hereinafter cited as 1959 House Obscenity Hearings). See also Statement of Hon. Herbert B. Warburton, General Counsel, Post Office Department, id. at 17.

2 Esquire v. Walker, 151 F.2d 49, 50, 55 (D.C. Cir. 1945).

3 For the defense of postal censorship, see generally 1959 House Obscenity Hearings. See especially Statement of the Postmaster General, $i d$. at 4, Statement of General Counsel, id. at 17 , and Symposium at Loyola University, $i d$. at 116.

For sweeping criticism of postal censorship, see generally CENSORSHTP BuLLETIN, published by the American Book Publishers Council; Emerson, The Doctrine of Prior Restraint, 20 LAw \& ConTEMP. РRов. 648 (1955); Lockhart \& McClure, Literahure, the Law of Obscenity, and the Constitution, 38 Mnnv. L. REv. 295 (1954); Paul \& Schwartz, Obscenily in the Mails, 106 U. PA. L. Rev. 214 (1957); Blanshard, THE Right to READ (1954). 
claimed power to censor for nearly a century, serious challenges have been forthcoming only since the end of World War II.

The Post Office has developed three administrative techniques for regulating the moral content of the mail: denial of second-class permit, blockade of incoming mail, and removal from the mail. The first denies the economic advantage of lower rates to obscene matter; the second prevents peddlers of obscenity in sealed first-class parcels from receiving the proceeds of their enterprise; the third represents ad hoc censorship of unsealed matter deposited for mailing. ${ }^{4}$ Each technique involves unique legal problems. ${ }^{5}$ Common to all three, however, is a single controversial assumption: that it is the proper business of the public delivery agency to regulate public morality. Postal censorsbip extends to fraud and subversion, but this comment is restricted to obscenity. ${ }^{6}$ Postal censorship of obscenity employs three techniques, but this comment is restricted to removal from the mail before delivery.

Succinctly stated, the argument against postal censorship by removal from the mail has four successive thrusts. (1) Nothing in the Constitution gives Congress the power to regulate the nation's reading matter. (2) Even if this power exists, no statute authorizes the Post Office to remove matter from the

118 U.S.C. \$1461. "Mailing obscene or crime-inciting matter. Every obscene, lewd, lascivious, or filthy book, pamphlet, picture, paper, letter, writing, print or other publication of an indecent character ... [Here follow six separate paragraphs describing classes of matter] ... is declared to be nonmailable and shall not be conveyed in the mails or delivered from any post office or by any letter carrier. Whoever knowingly deposits for mailing or delivery, anything declared by this section to be nonmailable, or knowingly takes the same from the mails for the purposes of circulating or disposing thereof, shall be fined not more than $\$ 5000$ or imprisoned not more than five years or both."

Mail suspected of obscenity by alert local postmasters is sent to the office of the General Counsel of the Post Office. Unless the General Counsel repudiates the postmaster's preliminary decision, notice of a mailability hearing is sent to the sender. At the hearing the sender may be represented by counsel; and the rules of procedure are carefully prescribed in the Code of Federal Regulations. Determination of mailability is entrusted to the Hearing Examiner. If the matter in question, judged by the current test for obscenity, is found mailable, it is immediately replaced in the mail. If it is found non-mailable, the sender is given fifteen days to reclaim it. 39 C.F.R. pt. 14 (1955), as amended, 39 C.F.R. $\$ 14.10$ (Supp. 1959); 22 Fed. Reg. 8999-9000 (1957). The process of removal is discussed at more length in deGrazia, Obscenity and the Mail: $A$ Study of Adminisirative Restraint, 20 LAW \& CONTEMP. PROB. 608 (1955).

${ }^{5}$ Hannegan v. Esquire, 327 U.S. 146 (1946) established the doctrine that second-class permits are not purely discretionary; but the Post Office continues to announce that obscene publications will be denied the privilege. House Obscenity Hearings (1959), supro note 1, at 18. The constitutionality of the practice of denial remains in doubt: on the one hand, it is purely an administrative decision; on the other, it is livelihood for second-class mailers.

The mail blockade statute, 64 Stat. 451 (1950), 39 U.S.C. $\$ 259$ (a) (1958), presents another type of problem. Under this statute, the postmaster is authorized to detain mail coming to a suspected peddler of pornography. When determination of the obscene character of the matter in question has been made, the postmaster is authorized to return to the sender all mail accumulated. The ultimate constitutionality of this section has not been tested; but several decisions have undermined the effect of the blockade. Tourlanes Pub. Co. v. Summerfield, 231 F.2d 773 (D.C. Cir. 1956); Glanzman v. Finkle, 150 F. Supp. 823 (E.D.N.Y. 1957).

- For discussion of postal censorship of political matter, see Paul \& Schwartz, Foreign Communist Propaganda in the Mails, 107 U. PA. X. REv. 621, 796 (1959). 
mail. (3) Even if this statute exists, removal from the mail is unconstitutional because it restricts freedom of speech. (4) The present practice of removal is intolerable because the procedure for determining nonmailability is inadequate. To survive intact, the Post Office must parry each thrust. Surprising as it may seem, the first three thrusts can apparently be parried; only the fourth threatens to upset the practice.

\section{CONGRESSIONAL POWER}

Seventy-five years ago the first and most basic thrust might have prevailed. In historical fact, it did not. Although the argument remains current, ${ }^{7}$ the history of constitutional law seems to have foreclosed the possibility of its acceptance. Article I, section 8, cl. 7 of the Constitution confers upon Congress the power to establish post offices and post roads. At least three distinct interpretations may be offered for this grant of power: ${ }^{8}$ (1) Congress may only establish efficient means for distributing the mail; it may make no law respecting the content of the mail. (2) Mail service is a privilege; and Congress may define as it will the limits of mailability. (3) Mail service is a right; and Congress may violate no rights protected by the Bill of Rights.

Congress accepted the second interpretation and passed a series of statutes excluding certain types of matter from the mail. ${ }^{9}$ At the turn of the century, congressional power to exclude was challenged and established. ${ }^{10}$ The first interpretation was rejected in situations where, if ever, it was most likely to prevail. Subsequent history of congressional power to regulate the mail has been a struggle between the second and third interpretations. ${ }^{11}$ With the influence of Holmes' tardy leadership, the theory of privilege has gradually yielded to the theory of right." ${ }^{12}$ Under the theory of right, Congress may regulate the postal

\footnotetext{
${ }^{7}$ For a strong statement against the power of the federal government to regulate sexual morality on a national level, see dissent by Harlan, J., in Roth v. United States, 354 U.S. 476, 496 et seq. (1957).

${ }^{8}$ The conflicting interpretations of the postal power are discussed critically and historically in Deutsch, Freedom of the Press and of the Mails, 36 Micn. L. REv. 703 (1938).

920 Stat. 360 (1879), lotteries and fraudulent schemes; 25 Stat. 873, 874 (1889), counterfeit money and fraudulent devices; 62 Stat. 781 (1948), foreign divorce information, poison, and explosives; 62 Stat. 782 (1948), miscellaneous. The categories of nonmailable matter are set forth in 39 C.F.R. pt. 14 (1955), as amended, 39 C.F.R. $\$ \S 14.5-14.10$ (Supp. 1959).

${ }^{10}$ Ex parte Jackson, 96 U.S. 727 (1877); In re Rapier, 143 U.S. 110 (1892); Lottery Case, 188 U.S. 321 (1903); Houghton v. Payne, 194 U.S. 88 (1904); Bates \& Guild Co. v. Payne, 194 U.S. 106 (1904); Public Clearing House v. Coyne, 194 U.S. 497 (1904); Knowles v. United States, 170 Fed. 409 (8th Cir. 1909). See Deutsch, op. cit. supra note 8, at 704.

11 The most dramatic episodes in the struggle occurred in the 'twenties,' when the Court extended the privilege doctrine over vigorous dissents by Folmes and Brandeis in Milwaukee Publishing Co. v. Burleson, 255 U.S. 407, 417, 436 (1921) and Leach v. Carlile, 258 U.S. 138, 140 (1922).

12 Pike v. Walker, 121 F.2d 37 (D.C. Cir. 1941); Hannegan v. Esquire, 327 U.S. 146 (1946); Cates v. Haderline, 342 U.S. 804 (1951). For an excellent analysis of the emerging theory of right, see Comment, The Esquire Case-A Novel Extension of the Postmaster General's Powers
} 
service as it will-so long as it respects the cluster of rights protected by the Bill of Rights. Thus, it would seem that obscene matter can properly be the subject of legislative exclusion unless protected by the first amendment.

\section{STATUTORY AUTHORITY}

Once congressional power is established, specific implementation of the power must be found. The Post Office contends that section 1461 authorizes removal of obscene matter from the mail..$^{13}$ Critics of postal censorship contend that section 1461 is nothing more than a criminal statute. ${ }^{14}$ Administrative censorship cannot be based on mere inference. The argument against authorization is based on the location, the wording, and the legislative history of section $1461 .{ }^{15}$ The section is found in Title 18, Criminal Code and Criminal Procedure; it explicitly provides for criminal penalty, but only indirectly hints at civil sanction; and, it is alleged, the congressional debates at the time of enacting and amending the statute indicate no intention to authorize postal censorship. Each of these arguments is questionable. Section 1461 was the sixteenth section of a general postal bill when first enacted in $1865 .{ }^{16} \mathrm{It}$ was subsequently amended and codified in Title 46, The Postal Service. ${ }^{17}$ Not until 1909 was it transferred to Title $69 \mathrm{~A}$, The Criminal Code..$^{18}$ Thus, it has not always been exclusively criminal. The wording of the statute states clearly that the proscribed matter is "nonmailable" and "shall not be carried in the mail." As even the critics acknowledge, ${ }^{19}$ longstanding congressional silence, in the face of removal by the Post Office, has entrenched the Post Office interpretation. The third argu-

of Classifying Mail, 53 YALE L.J. 733 (1944), written before the circuit court of appeals upset the administrative ruling. For discussion or the procedural side of the struggle between the privilege and right theories, see Cutler, The Post Office and the Administrative Practice Act, 47 Nw. U.L. REv. 72 (1952).

${ }^{13}$ The introductory paragraph on "Authority" to pt. 14 of 39 C.F.R. includes section 1461; pt. 14 defines mailability and indicates the sanctions used against nonmailable matter.

14 Three clear statements of the arguments against statutory authorization may be found in Paul \& Schwartz, op. cit. supra note 3, at 217 and at n.9; deGrazia, op. cit. supra note 4, at 611; Petition for a Writ of Certiorari, Roth v. United States, 354 U.S. 476 (1957).

${ }^{15} \mathrm{Ibid}$.

1613 Stat. 507 (1865).

1717 Stat. 302 (1872), 46 U.S. Coxr. STaT. $\$ 3893$ (1901).

${ }^{18}$ The statute was repealed from the postal section and enacted into the criminal section as part of a general scheme of consolidation. 35 Stat. 1153 (repealing); 35 Stat. 1129 (re-enacting). The statute was first numbered 211 of The Criminal Code and was codified in 69A U.S. Coxp. STAT. \$ 10381 (1913); 18 U.S.C. \$ 334 (1925); 18 U.S.C. \$ 1461 (1952).

${ }^{19}$ Paul \& Schwartz, op. cit. supra note 3 , at n.12. Even stronger evidence of congressional approval is found in the legislative history of the severe mail blockade statute. At the time of enacting the statute which would authorize the postmaster to return mail addressed to a known peddler of pornography, the House committee recognized the present practice of removal and quoted a letter written by Postmaster General Donaldson, in which he described briefly the removal process. 1950 U.S. CODE CoNG. \& AD. NEws, 3007-08. 
ment, concerming congressional debates, is the least tenable. The debates indicate that the statute from its first report was intended to be more than merely criminal. ${ }^{20}$

Finally, the controversy was carried to the federal courts; but still it remains unsettled. In Monart v. Christianberry (1958), ${ }^{21}$ the District Court for the Southern District of New York specifically approved the Post Office interpretation of section 1461. A dealer in photographs of nudes was denied injunctive relief from a nonmailability order..$^{22}$ The court addressed itself to the question of "whether the Postmaster General or his authorized delegates have administrative authority to reject this mail as nonmailable." ${ }^{23}$ The court held that section 1461, complemented by the enabling acts which permit the Postmaster General to do the work entrusted to him, ${ }^{24}$ "operates to close the mail to obscene matter." ${ }^{25}$ The only citation of authority was Roth 0. Goldman. ${ }^{26}$ Samuel Roth's Waggish Tales from the Czechs had been found obscene and nonmailable by the Post Office. His suit for relief, however, was not based on lack of statutory authority for removal. He raised only constitutional issues ${ }^{27}$ and was denied relief. Because the issue of statutory authority was not squarely met, consistent rejection of Roth's petition ${ }^{28}$ cannot be regarded as decisive authority for the Post Office interpretation of section 1461.

Twice since Roth v. Goldman, circuit courts of appeals have approved the contested interpretation. In One, Inc. v. Olesen, ${ }^{29}$ the Ninth Circuit approved removal from the mail of One, the Homosexual Magazine. The court considered the Postmaster General's interpretation of section 1461 sound; and it affirmed exclusion. In Sunshine Book Co. v. Summerfield, ${ }^{30}$ the D.C. Court of Appeals, sitting en banc, approved removal of Sunshine and Health, an international nudist magazine. Over a vigorous three-judge dissent, the court held that sec-

${ }^{20}$ The bill was reported from committee with provisions both for refusing to deliver obscene matter and for searching matter suspected of obscenity. On the floor of the Senate the provision permitting inspection of sealed matter was deleted; but the other portion, refusing admittance to the mail of obscene matter, remained and was enacted. CoNG. GLOBE, 38th Cong., 2d Sess., 660-62 (1865). See especially the interpretation by Senator Sherman of Ohio, who proposed revision of the amendment. Id. at 061.

${ }^{21} 168$ F. Supp. 654 (S.D.N.Y. 1958).

22 The non-mailability order had been entered against Monart after compliance with the procedures set forth in pt. 203, 39 C.F.R., noted above in note 4.

${ }^{23} 168$ F. Supp. at 655.

${ }^{25} 168$ F. Supp. at 655.

245 U.S.C. $\$ 22$ and $\$ 369(9)(1950)$.

26172 F.2d 788 (2d Cir. 1949).

${ }^{27}$ See petitioner's brief, prepared by Roth himself, filed with the Supreme Court to suppurt his petition for certiorari. Petitioner's Brief, Roth v. Goldman, 337 U.S. 938 (1949).

${ }^{28}$ Roth's petition for certiorari was denied. Roth v. Goldman, 337 U.S. 938 (1949). See also $\mathrm{n}$. 26, supra.

${ }^{29} 241$ F.2d 772 (9th Cir. 1957).

${ }^{30} 249$ F.2d 114 (D.C. Cir. 1957). 
tion 1461 authorizes removal before delivery. ${ }^{31}$ To the dissent's objection that power to remove was not clearly conferred by statute, the court countered by stressing the language of section 1461 and by looking beyond the statute to the necessity for such action. ${ }^{32}$ To compel the Post Office to postpone removal until after criminal conviction for mailing obscene matter is to defeat the purpose of the statute.

Both cases were subsequently reversed per curiam by the Supreme Court. ${ }^{33}$ What the reversals mean is a question for speculation. If the Court merely differed with the determination of obscenity, ${ }^{34}$ then the cases remain strong precedent for the position taken by the Post Office. If, however, the Court cut deeper and objected to the postal practice of removal from the mail, then the Post Office interpretation of section 1461 was quietly rejected. Although the latter hypothesis is extremely unlikely, it will remain a possible explanation until the Court clarifies its views on obscenity in the mail.

Despite the ambiguity of the One, Inc. and Sunshine Book cases, the Post Office seems to have a statutory mandate to remove matter from the mail. The statute has been more than criminal from its inception; and the courts have consistently refused to enjoin removal from the mail of matter properly found to be obscene. ${ }^{35}$ It will require legislative revision or explicit judicial repudiation to change the course of postal practices.

\section{Free Speech}

The threat of punishment for mailing obscene matter restricts permissible expression. ${ }^{36}$ Persons prosecuted under section 1461, supported by earnest advocates of civil liberties, ${ }^{37}$ have endeavored to demonstrate that this restriction

a1 "The statute under which the proceedings went forward not only makes criminal the use of the mails for the transmission of proscribed matter, including obscene, lewd or lascivious pictures or publications of an indecent character, but all such matter is declared to be 'nonmailable' and 'shall not be conveyed in the mails.' "Id. at 117. Fahy, J., concurring, was equally explicit. See the first paragraph of his opinion, id. at 120. The dissent stressed the absence of specific mandate for removal, second of the three arguments against removal noted above. Id. at 121.

Id. at 119.

${ }^{33}$ One, Inc. v. Olesen, rev'd per curiam, 355 U.S. 371 (1958); Sunshine Book Co. v. Summerfield, rev'd per curiam, 355 U.S. 372 (1958).

34 This explanation has been suggested in several studies of the Supreme Court's action. See Comment, 26 U. CHr. I. REv. 309 (1958); Note, The Supreme Court and Obscenity, 11 VAND. L. REV. 585, 594 (1958); Symposizum at Loyola University, reprinted in House Obscenity Hearing (1959) at 116.

35 Walker v. Popenoe, 149 F.2d 511 (D.C. Cir. 1945), occasionally cited for the contrary, held only that the given matter, a marriage manual, was not obscene. The alternative holding, written as a concurring opinion by Arnold, J., with full support of his colleagues, declared the particular post office order invalid because no hearing had been held.

36 Frank, J., concurring in United States v. Roth, 237 F.2d 796, 801 (1956), discussed the application of this fundamental principle of deterrence to the crime of mailing obscene matter.

${ }^{37}$ See, e.g., articles cited op. cit. supra note 14. 
is contrary to the first amendment's guarantee of free speech. The endeavor has failed. In Roth v. United States, ${ }^{38}$ the Supreme Court expressly declared the criminal sanction of section 1461 to be constitutional. The Court recognized an outer limit to speech protected by the first amendment and declared obscenity to be beyond the limit. Obscenity was grouped with profane fighting words ${ }^{39}$ and group libel ${ }^{40}$ as forms of expression unworthy of protection by the first and fourteenth amendments.

The test applied was one of social value. ${ }^{41} \mathrm{Mr}$. Justice Murphy, writing for the Court in Chaplinsky v. New Hampshire, ${ }^{42}$ had explained the test of social value: "such utterances are no essential part of any exposition of ideas, and are of such slight social value as a step to truth that any benefit that may be derived from them is clearly outweighed by the social interest in order and morality." Applying this test to obscenity, as a form of expression, the Court in Roth concluded that obscenity too is beyond the limit of constitutionally protected speech. ${ }^{43}$

When section 1461 is extended from criminal prosecution to proscription before delivery, it is not difficult to find the operation of prior restraint. Critics of postal censorship attempt to evoke traditional dislike of prior restraints. ${ }^{44}$ Unlike subsequent punishment, which is indirect censorship, prior restraint censors by direction. The particular object may be seized, judged, and con-

${ }^{38}$ Supra note 7.

${ }^{39}$ Chaplinsky v. New Hampshire, 315 U.S. 568 (1942).

${ }^{40}$ Beauharnais v. Illinois, 343 U.S. 250 (1952).

11 The "clear and present danger" test has been advanced as the only constitutional limitation upon freedom of expression. For argument that proscription of obscenity can be justified only be meeting the "clear and present danger" test, see Bok, J., Commonwealth v. Gordon, 66 Pa. D. \& C. 101 (1949); Comment, Censorship of Obscene Literature, 52 MrcH. L. REv. 575 (1954); Comment, Postal Sanctions: A Study of the Summary Use of Administrative Power, 31 IND. L.J. 257 (1956). This doctrine simply was not available to the Court. More than probable harm must be proved in order to invoke that limitation on free speech (see the analysis of "clear and present danger" cases in concurring opinion by Frankfurter, J., Dennis v. United States, 341 U.S. 494, 517 (1951)); and the social harm of obscenity cannot be proved.

The causal connection between obscenity and antisocial behavior is thoroughly discussed in the Appendix to the concurring opinion of Frank, J., United States v. Roth, supra note 36. Frank analyzed the most able scientific studies of the problem and set forth his conclusion that causation cannot be proved, or even shown to be probable. For evidence and argument to the contrary, however, see House Obscenity Hearing (1959), supra note 1; Symposium at Loyola University, supra note 34 .

315 U.S. at 572.

43 If more situations arise for determination by the "social value" test, it will be interesting to discover the limitations of the doctrine. As with the "clear and present danger" test, social evaluation by both legislature and judiciary must agree before the contested law is valid. Even more than the "clear and present danger" test, the "social value" test self-consciously admits the temporary striking of a balance. This would seem to indicate that rejection of any particular application of the doctrine is easy. Unlike rediscovery of the "true rule," this form of decision is admittedly temporary.

14 For an excellent analysis of the operation of prior restraints, written by an avowed critic, see Emerson, op. cit. supra note 3. 
demned. The classic example is the series of licensing acts in seventeenth-century England. ${ }^{45}$ It was against these acts that Milton inveighed so eloquently in Areopagitica. ${ }^{46}$ It was freedom from those acts which Blackstone acknowledged so gratefully in the Commentaries. ${ }^{47}$ A proposal that the federal government resurrect licensing acts by requiring that all books, pamphlets, and periodicals published in this country be submitted to a screening test for obscenity would doubtless raise a loud cry of popular indignation. It is doubtful that such a sweeping measure would pass the test of constitutionality.

It might be thought that cases involving censorship of motion pictures would long since have decided whether such licensing is constitutional; unfortunately, this has not happened. Individual cities and states require that all films be screened and approved before exhibition. ${ }^{48}$ Not yet, however, has the Supreme Court indicated whether such laws, functioning as prior restraints upon freedom of expression, are constitutional. Several acts have been invalidated because they purported to establish vague, general tests for proscription, ${ }^{49}$ broader than obscenity as defined by Roth or the Model Penal Code. ${ }^{50}$ Instances of censorship under other laws have been reversed because the films were found not obscene. ${ }^{.1}$ State court opinions in film censorship cases may give some indication whether prior restraint of obscenity is constitutional ${ }^{62}$ but the issue has not been settled firmly.

Even if licensing should be found unconstitutional, postal censorship need not fall. Removal differs from licensing. The differences seem significant enough

${ }^{45}$ See 6 Holdsworti, History of ENGLish LAW 367-378 (1924 ed.).

${ }^{16}$ See especially the first three pages of Mrrion, AREOPAGrtica (Everyman's ed. 1941).

17 "The liberty of the press is indeed essential to the nature of a free state; but this consists in laying no previons restraints upon publications, and not in freedom from censure for criminal matter when published. Every freeman has an undoubted right to lay what sentiments he pleases before the public: to forbid this is to destroy the freedom of the press: but if he published what is improper, mischievous, or illegal, he must take the consequences of his own temerity." 4 BLACKSTONE, CoManENTARIES 150-51.

48 Three censorship laws which have given rise to extensive litigation are ch. 155 of the Municipal Code of Chicago; Ohio Rev. Code $\$ 3305.04$ (1953); N.Y. Education Law $\$ 122$. See Nimmer, The Constitutionality of Official Censorship of Motion Pictures, 25 U. CHr. L. REv. 625 (1958) for references to other statutes and ordinances.

49 Joseph Burstyn, Inc. v. Wilson, 343 U.S. 495 (1952); Kingsley Int'l Pictures Corp. v. Regents of Univ. of New York, 360 U.S. 684 (1959).

so Tentative Draft \#6 of the Model Penal Code (1957) was the source of the test announced in Roth; "whether to the average person, applying contemporary community standards, the dominant theme of the material, taken as a whole, appeals to prurient interest." 354 U.S. at 489 .

31 Times Film Corp. v. Chicago, 355 U.S. 35 (1957). See discussion of Times Film and other cases on point in Nimmer, op. cit. supra note 48 , at 629.

52 Chief Justice Schaefer studied the relationship between postal censorship and motion picture censorship in his opinion for the Illinois Supreme Court in American Civil Liberties Union v. Chicago, 3 Ill.2d 334 (1954). In upholding the ordinance, he recognized the ambiguity of precedent, rejected the clear and present danger requirement, and pleaded for extensive judicial review. 
to enable it to escape the opprobrium aimed at licensing acts. An unlicensed book or film cannot legally be submitted to the public. No one can see the matter except the producers and the censors. Every attempt to avoid licensing is a crime; the restraint is total. Removal from the mail, however, technically does not prohibit publication. The matter may be produced and distributed in other commercial channels within the state of production ${ }^{53}$ with no interference by the federal government. Although this distinction might have been persuasive fifty years ago, during the ascendance of the privilege theory of postal service, it is weak today. Denial of postal service to many publishers, especially publishers of periodicals, is effective destruction of their enterprise. The restraint, seen by practical men, is total.

Second, the burden of initiation is on the censor. Unlike licensing laws which require the producer to seek the seal of approval, section 1461 at most empowers the postmaster to detain for decision matter which he considers obscene. The producer need not deviate from the usual course of his commerce enterprise.

The precedent which may be controlling is Kingsley Books v. Brown. $.^{54} \mathrm{Al}-$ though that case did not involve administrative prior restraint, the Court specifically approved an injunction against the sale of an obscene book. ${ }^{55}$ The operation and effect of prior restraints demanded attention. Mr. Justice Frankfurter, writing for the Court, minimized the practical differences between subsequent punishment and prior restraint. Because the burden was on the state, because the action was in a federal court, and because speed was provided, the Court found that the procedural safeguards prevented violation of the defendant's freedom of speech. Although three dissenters, Warren, Douglas, and Black, ${ }^{56}$ opposed all forms of noncriminal prior restraint, Mr. Justice Brennan based his dissent on procedural objections. ${ }^{57}$ Because no jury considered the obscenity of the proscribed book, its sale should not have been enjoined. The precedent value of Kingsley Books is presently ambiguous: it may represent rejection of constitutional objections to prior restraint; or it may become the limiting case for procedural safeguards. All subsequent attempts at prior restraint may have to match the safeguards of the New York statute.

\section{Procedural Objection}

Whether or not removal is invalidated as an unconstitutional restraint upon free speech, the procedural objections to administrative censorship remain interesting. Three troublesome questions are raised by the present practice: (1) Can removal prior to hearing be justified? (2) Should judicial review be extensive? (3) Should the Hearing Examiner continue to make the initial decision?

\footnotetext{
${ }^{53}$ Addition of the predecessor to 18 U.S.C. $\$ 1462$ (1950) made the intrastate qualification necessary. 29 Stat. 512 (1897).

54354 U.S. 436 (1957).

55 "Nights of Horror" was enjoined from sale pursuant to N.Y. CODE OF CRIM. \$22-a.

56 354 U.S. at $445,446$.

57 354 U.S. at 447 .
} 
For the mailer of periodical literature, time is of the essence. Delay of even a few days may damage his business reputation. This renders scheduling a hearing very difficult: if the matter is detained before the hearing, hardship results; if the matter is allowed to proceed, the postal censorship is vain. All copies of the questioned matter will probably reach their destinations before the mailability hearing can issue an effective order. In the one obscenity case which confronted the problem, the court held that hardship to the sender is the lesser evil. ${ }^{58}$ The D.C. Court of Appeals, sitting en banc, recognized the necessity for action before hearing; but the dissent objected violently. The three-judge dissent contended that section 1461 authorizes removal only of matter found obscene in a previous criminal trial. ${ }^{59}$ Extension to include removal of matter pending determination of its obscenity seemed unwarranted and indefensible.

Useful analogies may be found in other areas where confiscation before hearing has been attempted. Under the doctrine of emergency, ${ }^{60}$ health officials have been held constitutionally able to condemn and confiscate matter dangerous to public health. ${ }^{61}$ Were public health the only end-in-view which justified confiscation prior to formal hearing, the Post Office would have difficulty proving its right to remove matter from the mail under section 1461. No competent social evaluation is available $;^{62}$ and Post Office counsel would be hard pressed to demonstrate the detrimental effect of obscene matter.

Emergency, as an exception to the requirement of hearing before confiscation, has not been limited to public health. Public health has shaded into public welfare. Protection of the public from misleading advertising justified confiscation in Eving v. Mytinger $\&^{\circ}$ Casselberry..$^{63} \mathrm{M} \& \mathrm{C}$ attempted to distribute to the public a vitamin compound with a brochure describing the many wonders it would perform. The Director of Health instituted multiple libels against the compound under section 334(a) of the Federal Food, Drug, and Cosmetic Act. There was no allegation that the compound was dangerous to health; the Director needed only probable cause to believe the misbranded article misleading to the injury or damage of the customer. The Court justified the confiscation by drawing the analogy to imprisonment pending trial: the institution of any judicial proceedings may involve hardship.

Although brought to confiscate another type of product under another federal statute, the confiscation in Mytinger $E^{\circ}$ Casselberry is very similar to re-

${ }^{58}$ Sunshine Book Co. v. Summerfield, 249 F.2d 114 (D.C. Cir. 1957).

${ }^{59} \mathrm{Id}$. at 121.

5o See Jafre, Admisistratrve Law, Cases and Materials 301 (1954); 1 Davis, AdminISTRATTVE LAW TREATISE $\$ 7.08$ (1958).

61 North American Cold Storage Co. v. Chicago, 211 U.S. 306 (1908) is the classic case. The Supreme Court held that seizure of putrid poultry by Chicago health officials was not denial of due process. The poultry endangered public health; and a hearing could be held after the fact.

62 See materials cited note 34 supra.

${ }^{63} 339$ U.S. 594 (1950). 
moval by the Post Office. Both measures are preparatory to a formal administrative hearing; and indeed each is necessary if the hearing is to have much effect. Both measures purport to protect the public welfare; but neither rests on demonstrable proof of immediate social harm. There is, however, one important difference. Whereas the statute involved in Mytinger $\&^{\circ}$ Casselberry sets forth the procedure by which the Secretary may institute the libel proceedings, section 1461 merely declares certain types of mail to be nonmailable. The wedge of distinction might be driven between the two situations, striking down removal from the mail as statutorily too vague to permit action before hearing.

For criminal conviction under section 1461, the prosecution must convince a jury that the contested matter is obscene. ${ }^{64}$ The Roth test is a community standard, analogous to the standard of due care, ${ }^{65}$ and a jury is peculiarly able to apply the standard. ${ }^{66}$ For removal from the mail under section 1461 , however, the opinion of no jury is required. The Post Office Hearing Examiner is the factfinder ${ }^{67}$ it is his task to apply the community standard to the contested matter. The Hearing Examiner has no innate competence to represent the community conscience. Indeed, the relative merits of jury and administrator are reversed for application of the Roth test. Often the administrator has specialized knowledge, based on experience, which entitles his opinion to greater weight than a jury verdict would deserve. But here the test to be applied was framed specifcally for use by a jury; and the administrator takes merely by procedural default. No jury is provided; and he must decide.

Under present practice, the Hearing Examiner determines obscenity; and his finding becomes a "departmental decision" upon ratification by either the Judicial Officer or the Postmaster General. ${ }^{68}$ From this departmental decision, the only recourse is to petition a federal district court for an injunction against enforcement of the order. The right to judicial review of nonmailability orders is settled; but the scope of review remains undefined.

The Administrative Procedure Act provides that "the reviewing court shall decide all relevant questions of law, interpret constitutional and statutory provisions" and set aside action "unsupported by substantial evidence."69 Conflicting interpretations of the type of question posed by obscenity have led to wide variation in the application of this section. The diversity of disposition can be appreciated by contrasting two extreme cases. The Court of Appeals in One, Inc.

64 Because the punishment prescribed in $\$ 1461$ makes the crime a felony, the accused sender may demand jury trial. In fact, however, many senders prefer to place the case before a judge.

5 Supra note 50.

66 "There can never be constitutive principles for such judgments, or indeed more than cautions to avoid the personal aberrations of the jurors ... . Thus "obscenity" is a function of many variables, and the verdict of the jury is not the conclusion of a syllogism of which they are to find only the minor premise, but really a small bit of legislation $a d$ hoc, like the standard of care." L. Hand, J., United States v. Levine, 83 F.2d 156, 157 (2d Cir. 1936).

6739 C.F.R. pt. 203 (1955).

${ }^{68} 24$ Fed. Reg. 4026, §203.12 (1958).

6260 Stat. 243 (1946), 5 U.S.C. $\$ 1009$ (e) (1958). 
considered obscenity a question of fact or an administrative question ${ }^{70}$ and tested only the rational basis for a finding of obscenity. The court in Grove Press v. Christianberry $y^{71}$ considered obscenity a question of law or judicial question and freely substituted its own judgment for the finding of the administrator. In the interest of symmetry and predictability, one of these techniques must yield. The broader scope of review, found in Grove Press, seems preferable.

Analysis of cases contesting the scope of review discloses a complex series of factors which influence the extent to which federal courts will substitute judgment for administrative decisions. ${ }^{72}$ If any consensus can be reached, the following five factors are the most significant: (1) qualification or expertise, ${ }^{73}$ (2) congressional intent, ${ }^{74}$ (3) sensitivity of the area of law, ${ }^{75}$ (4) confinement

${ }^{70}$ Mr. Justice Roberts, dissenting in NLRB v. Hearst Publications, 322 U.S. 111 (1944), rejected the traditional distinction between "questions of fact" and "questions of law" and attempted to substitute distinction between "administrative questions" and "judicial questions." Admittedly the new terminology would provide answers to no specific cases. It would, however, abolish the imprecise distinction currently and fumblingly employed. The new terminology would require careful study of case-law, rather than extend the vain hope of a logical distinction. Davis regretfully notes, however, that the law has not adopted Mr. Justice Roberts' suggestion. 4 Davis op. cit. supra note 58, at 194.

"As we view this case we are only concerned with the proper application of a postal regulation, a prosaic and every day [sic] matter of the post office department. Section 1461 amounts to no more than that. ... Unless we find that the initial order of the Postmaster barring the magazine from the mails was arbitrary, or capricious, or an abuse of discretion, or that there are no reasonable grounds in the record to support the District Court in upholding the Postmaster's order, we are required to sustain." One, Inc. v. Olesen, 241 F.2d 772, 774-75 (1957).

71 "The Administrative Procedure Act makes the reviewing court responsible for determining all relevant questions of law, for interpreting and applying all constitutional and statutory provisions and for setting aside agency action not in accordance with law. 5 U.S.C.A. $\$ 1009$. The question presented here falls within this framework. Thus, the question presented for decision is whether 'Lady Chatterley's Lover' is obscene within the meaning of the statute and thus excludable from constitutional protections. I will now consider that question." Grove Press v. Christenberry, 175 F. Supp. 488, 496 (S.D.N.Y. 1959).

72 Because the distinction between law and fact is never easy to discern, the ambivalence of reviewability is not unique to obscenity cases. Scholars of administrative law have endeavored to explain in comprehensive style variations in review. See 4 Davis $o p$. cit. supra note 58 ch. 30; Kramer, The Place and Function of Judicial Review in the Adminisirative Process, 28 Fordiasr L. Rev. 1 (1959); Schwartz, Gray o. Powell and the Scope of Review, 54 Mich. L. REV. 1 (1955).

${ }^{73}$ If an administrator has developed expertise in his area, reviewing courts are reluctant to overturn his decisions. 4 DAvIs op. cit. supra note $58 \$ 30.09$. Although it may be argued that the Post Office Hearing Examiner should know the precedents of obscenity, the test of obscenity is a community standard-beyond the expertise of postal officials. In the absence of administrative expertise, the courts find superior qualification for decision in themselves. $4 \mathrm{id}$. at 241.

${ }^{74}$ If it is clear from the legislation or from legislative history that Congress intended the administrative decision to stand, the courts are reluctant to substitute judgment. 4 Davis op. cit. supra note 58, at $\$ 30.10$. Congress has made no indication that administrative finding of obscenity is to be accorded special respect. The provision for mailability hearings is administrative in source, not legislative; therefore, limited review is not inferable from legislative intent.

${ }^{75}$ In an area where public sympathy is strong and precious freedoms are at stake, courts are often less reluctant to review administrative decisions. 4 DAvIs op. cit. supra note 58 , at 232. 
of the particular decision, (5) formality of the administrative adjudication. ${ }^{76}$ Determination of obscenity, measured by these factors, is a question for which extensive review should be available. Grove Press v. Christianberry is persuasive precedent; and already the reluctance to review, seen in $C_{n e}$, Inc., may be outmoded.

"Review of bad decisions will never take the place of good decisions in the first instance." Even the best judicial review cannot restore wasted time and effort. To compel senders of mail, found obscene by the Post Office, to exhaust administrative remedies and then to petition for injunctive relief works a double hardship. The matter is detained from the mail for a long time; and the burden of entering the federal courts is placed on the sender. In an area as sensitive as freedom of speech, this double hardship is magnified and may become intolerable. To remedy the situation, the initial determination of obscenity might be taken from the Hearing Examiner. Several approaches are possible.

(1) A jury might be incorporated into the administrative procedure. The mailability hearing would continue to be directed by a Hearing Examiner, with oral arguments by the General Counsel and by the sender's counsel; but the determination of obscenity would be by a jury. This change would have the advantage of securing competent application of the community standard without removing the hearing from the Post Office. There are, however, two distinct problems: conduct of the hearing by an administrator and composition of the jury. Only if expert testimony is excluded or limited ${ }^{78}$ and if a suitable standard charge could be formulated, would the Hearing Examiner be able to conduct the hearing properly. Presumably the jury would be drawn from citizens of Washington, D.C., site of the Mailability Division of the Post Office. This would tend to impose the standards of one locale upon the whole nation. Even if the hearings were held at the city of mailing, however, similar problems would exist, because most mailings of suspect periodicals are not confined to the area

${ }^{76}$ Confinement and formality are safeguards against abuse of the administrative process. A formal hearing for each matter in question is less likely to lead to oppressive results than casual administrative rulings which may immediately affect many people; and the courts are less eager to impose judicial review. 4 DAvis op. cit. supra note 58 at 238; Kramer, op. cit. supra note 70, pt. VII; Schwartz, op. cit. supra note 70, at 40. Trust in the fairness of administrative hearings, when protected by formal rules separating functions, is part of the larger concept of confidence in the particular agency. Confidence, basically, is the underlying factor determining judicial review.

77 Gellerorn, Individual Freedom and Governmental Restratnis 95 (1956).

78 Whether expert testimony as to obscenity will be admitted, either at the mailability hearing or upon review, is unsettled. The Model Penal Code, Tentative Draft \#6, strongly recommends admission of evidence to show (1) what the probable audience is for the matter in question, (2) what the appeal is for that audience, (3) what artistic, scientific, or educational value the matter possesses, (4) what degree of acceptance similar matter has attained, (5) what appeal the advertising of the matter has. Mr. Justice Frankfurter based his concurring opinion in Smith v. California, 4 L.Ed.2d 205, 215 (1959), on failure of the trial court to admit such testimony; but the majority did not reach the question. 
of deposit; and the jury drawn from that area again might not be representative. $^{79}$

(2) A second possibility is requirement of a court order before exclusion from the mail. With probable cause to believe matter deposited for mailing to be obscene, the Post Office General Counsel could petition a federal court for an injunction. ${ }^{80}$ Probably a preliminary injunction would be permitted. This alternative would conform to the procedural safeguards found constitutional in Kingsley Books, but would leave other problems unsolved. From the viewpoint of the Post Office, the procedure would be unacceptable. It would deny to the Post Office the power to determine what matter it will carry; and it would probably result in removal of less matter from the mail. ${ }^{81}$ The procedure would also be unacceptable to those who take seriously the concept of community standard. Still the determination would be by one person, little more qualified to apply a community standard.

(3) The third alternative combines the changes of the former two. An advisory jury could be added to the federal district court to determine whether the matter objected to by the Post Office is indeed obscene. This procedure, suggested generally by Professor Paul Freund as a safeguard against the possible dangers of prior restraint, ${ }^{82}$ would provide the maximum safety for mailers of suspect matter. Only the intransigent few who oppose all forms of prior restraint would attack this procedure from the one side. From the other side, however, would come bitter attack. To require the Post Office to go into court and to convince a jury that matter removed from the mail is obscene is to cramp the effectiveness of Post Office restriction of the mail. Again problems of location and evidence come to the fore; but it may be possible to devise a system both speedy and safe.

\section{Concluston}

Procedure is probably the most vulnerable area in this improbable process of censorship by the Post Office. Even if the present practice is not held unconstitutional for want of procedural safeguards, it is likely that the courts will quietly

79 Note the recent amendment to $\$ 1461$ which permits prosecution in the jurisdiction of receipt. 72 Stat. 962 (1958). By this amendment Congress expected to convict more mailers of obscenity by imposing stricter standards of the hinterlands. 1958 U.S. CoDE CoNG. \& ADUnN. NEWS 4012 .

${ }^{80}$ This is the procedure used by Customs to prevent importation of obscene matter. There are important differences between importation and internal circulation, however, which complicate the analogy. The bulk of domestic mail suspected of obscenity is much larger than the bulk of imported matter. Furthermore, the Customs Bureau confessedly follows the Post Office standards in making decisions to sue for confiscation. See generally CHAFEe, GoverNMENT \& Mass Cosaronicamtons 242 el seq. (1947). Change of Post Office Procedure would be a greater strain on the courts and would necessitate change in Customs policies.

81 1959 House Obscenity Hearings, especially remarks by Summerfield and Warburton, supra note 1.

* Freund, The Supreme Court and Civil Liberties, 4 VAND. L. REv. 533, 539 (1951). 
insist on extensive judicial review. ${ }^{83} \mathrm{It}$ is ironic that this, the fourth of the major thrusts of attack outlined above, is most likely to effect a change in the present practice. Critics of the practice would prefer to defeat it by exposing its baselessness or its outrageousness. No constitutional authority to regulate morals exists; no statutory authority to remove matter from the mail can be found; no restriction upon freedom of speech is tolerable. These arguments, abstractly persuasive, yield to the reality of history and precedent. Congress does in fact have power to decide-within limits-what matter will be carried in the mail. Section 1461 has authorized removal of obscene matter from the mail. Matter which is indeed obscene is not protected from congressional proscription by the first amendment. Only the procedure for determining obscenity may be successfully attacked; expansion of judicial review will relieve most of the pressure there. What probably will survive is censorship of an ill-definable collection of matter by the federal letter-carrying agency under the watchful eye of federal courts.

${ }^{83} \mathrm{It}$ is possible that judicial insistence upon extensive review will lead to relocation of the initial decision. If the majority of senders of matter found nonmailable appeal the administrative determination, the Post Office hearing will become meaningless. The relocation may take any of the forms suggested above.

\section{STRIKE SUPERSENIORITY: VALID EXTENSION OF NLRB v. MACKAY RADIO AND TELEGRAPH OR VIOLATION OF SECTION 8(a)(3) OF THE NLRA?}

In NLRB. v. Mackay Radio \& Telegraph Co., ${ }^{1}$ the Supreme Court ruled that an employer had the right permanently to replace economic strikers. ${ }^{2}$ Although the Court recognized that its ruling would indirectly inhibit employees in the exercise of their right to strike, ${ }^{3}$ the Court gave paramount weight to the right of the employer "to protect and continue his business by supplying places left

1304 U.S. 333 (1938).

2 The Mackay decision and other cases dealing with the reinstatement or discharge of strikers under the NLRA distinguish between current labor dispute strikes (often called economic strikes) and strikes brought about by an employer's unfair labor practice. The distinction originates in the wording of section 2(3) of the Act. The Mackay doctrine is limited to economic strikes. In the case of an unfair labor practice strike, the strikers are entitled to reinstatement notwithstanding the hiring of replacements during the strike, and their reinstatement must be unconditional, as though they had not been absent from work. NLRB v. Mackay Radio and Telegraph Co., 304 U.S. 333, 344-45 (1938); NLRB v. Sartorius \& Co., 140 F.2d 203, 206 (2d Cir. 1944); Polish National Alliance v. NLRB, 136 F.2d 175, 181 (7th Cir. 1943); Republic Steel Corp. v. NLRB, 114 F.2d 820, 821 (3d Cir. 1940).

${ }^{3}$ Section 7 of the National Labor Relations Act, 49 Stat. 452 (1935), as amended, 61 Stat. 140 (1947), 29 U.S.C. $\$ 157$ (1958), accords employees general but not unqualified protection to "engage in . . . concerted activities for the purpose of collective bargaining or other mutual aid or protection"; while section 2(3), 49 Stat. 450 (1935), as amended, 61 Stat. 137 (1947), 29 U.S.C. $\$ 152(3)$ (1958), preserves to strikers their protected status as employees under the Act. 